A Journal of Culture, English Language, Teaching \& Literature ISSN 1414-3320 (Print), ISSN 2502-4914 (Online)

Vol. 20 No.1; June 2020

Copyright (@) Soegijapranata Catholic University, Indonesia

Students' Perceptions on English Fun Fair as an Implementation of Project-Based Learning in Speaking for Social Purposes Classes

${ }^{1}$ Ardela Indri Apriliani and ${ }^{2}$ Listyani

${ }^{1,2}$ English Language Education Program, Faculty of Language and Arts, Universitas Satya Wacana, Salatiga, Indonesia email: 112016034@student.uksw.edu, listyani.listyani@uksw.edu

Received: 21-12-2019 Accepted: 08-12-2020 Published: 05-06-2020 


\title{
Students' Perceptions on English Fun Fair as an Implementation of Project-Based Learning in Speaking for Social Purposes Classes
}

\author{
${ }^{1}$ Ardela Indri Apriliani and ${ }^{2}$ Listyani \\ 1112016034@student.uksw.edu, ${ }^{2}$ listyani.listyani@uksw.edu \\ 1,2 English Language Education Program, Faculty of Language \\ and Arts, Universitas Satya Wacana, Salatiga, Indonesia
}

\begin{abstract}
English Fun Fair is one of the implementation models in Project-Based Learning (PBL) which involves learning through various tasks and collaborative learning. Particularly, the project was implemented in Speaking for Social Purposes classes at an English Language Education Program, at a private university in Central Java, Indonesia. The study aimed to investigate students' perceptions of the influence of English Fun Fair which consisted of the benefits and challenges of the project. The participants of the study were fifty (50) students from 2016, 2017, and 2018 Academic Year who had taken Speaking for Social Purposes course and had done English Fun Fair. To gain data more deeply, the researchers used a qualitative method. The instruments used were open-ended questionnaires and semi-structured interviews. In the questionnaires, the participants answered some questions related to this study. After that, as a follow-up of the answers in the questionnaires, the researcher did interviews. Besides that, the data showed that improving speaking skills was the most dominant benefit mentioned by the participants. However, problems in speaking skills also became a challenge which they experienced a lot. Expectantly, the findings from this study can give views for EFL teachers about the benefits of this project and for EFL students can develop their speaking and other skills.
\end{abstract}

Key words: English Fun Fair, PBL, perceptions, speaking skills, Speaking for Social Purposes

Abstrak: English Fun Fair merupakan salah satu penerapan ProjectBased Learning (PBL) yang melibatkan pembelajaran melahi berbagai tugas dan pembelajaran kolaboratif. Secara khusus, projek ini 
74 Celt: A Journal of Culture, English Language Teaching \& Literature, Volume 20, Number 1, June 2020, pp. 73-95

dilaksanakan pada kelas Sepaking for Social Purposes pada sebuah Program Studi Pendidikan Bahasa Inggris di sebuah universitas swasta di Jawa Tengah, Indonesia. Penelitian ini bertujuan untuk mengetahui persepsi mahasiswa tentang pengaruh English Fun Fair, khususnya tentang tantangan serta manfaat, yang dirasakan oleh mahasiswa responden. Responden penelitian terdiri dari 50 mahasiswa angkatan tahun 2016, 2017, dan 2018 yang telah mengambil mata kuliah Speaking for Special Purposes dan telah mengikuti acara English Fun Fair. Dalam penelitian kualitiatif ini, data diperoleh dari kuesioner dan wawancara semi tersruktur. Hasil penelitian menunjukkan bahwa peningkatan ketrampilan berbicara merupakan manfaat paling utama yang dirasakan oleh responden. Namun demikian, masalah dalam ketrampilan berbicara juga menjadi tantangan bagi banyak mahasiswa. Diharapkan hasil penelitian ini dapat memberikan manfaat bagi guru ataupun dosen EFL serta para siswa atau mahasiwa dalam mengembangkan kemampuan siswa/ mahasiswa dalam berbicara dalam Bahasa Inggris.

Kata kunci: English Fun Fair, PBL, persepsi, ketrampilan berbicara, Speaking for Social Purposes

\section{INTRODUCTION}

In this modern era, English is one of the languages which has an important role in international communication. Along with the development of society, countries become increasingly multicultural. Everyone's understanding depends on communication. It is because people who come from different countries will be confused in understanding each other if they do not use English in speaking. Besides that, among the four skills in English, speaking becomes the most essential skill (Ur, 1996). Thus, English Foreign Language (EFL) students have to master the speaking skill to communicate with each other.

However, there are a lot of people in Indonesia who still get difficulty in speaking English, especially for EFL students. This can happen because they have to be proficient to speak English which is not their native language. Furthermore, most students are not confident in speaking English. This is also supported by Hadijah (2014) who stated that students face their own personal problem including lack of confidence, lack of practice in speaking, and shy to speak English. 
On the other hand, there was a study conducted in Islamic Azad University of Chabahar (IAUC). The university applied Project-Based Learning (PBL) as the model for teaching speaking. The result revealed that "PBL has significant effect on speaking ability of elementary adult EFL learners" (Behtash \& Sarlak, 2017, p. 129). At the private university in Central Java, Indonesia, where the research was conducted, PBL was also implemented as one of the speaking class activities.

One of the PBL models is English Fun Fair which is a project in Speaking for Social Purposes classes. Therefore, we perceived the need to investigate further about English Fun Fair. Specifically, the research was aimed to answer the research question: What are students' perceptions on English Fun Fair as the implementation of Project-Based Learning (PBL) model in Speaking for Social Purposes classes?

Moreover, the study aimed to explore students' perceptions about the influences of English Fun Fair in learning process. Hopefully, this study can be beneficial for ELEP lecturers and students, especially in improving students' speaking skills. Lecturers can take the information about the benefits of English Fun Fair as a project in speaking classes. Also, they can give a contribution to PBL in teaching speaking. Besides that, students can develop and enhance speaking skills and other skills in their learning process.

\section{LITERATURE REVIEW}

This section provided all the information related to the research. The first part explained the definitions of speaking. The second part analyzed the concept of teaching speaking. The third part explained the definitions of Project-Based Learning (PBL). The fourth part described the advantages of Project-Based Learning (PBL). The fifth part elaborated on the concept of English Fun Fair. Also, the last part justified previous studies on Project-Based Learning (PBL) and theoretical framework.

\section{A. The Definitions of Speaking}

There are various definitions of the speaking term itself. An interactive process which contains producing, receiving, and processing speech of sounds as the main instruments can be called as speaking (Brown, 2001) as cited in Suryani (2015). Cameron (2005) as cited in Suryani (2015) said that through speaking, people can understand the meaning which is expressed by other 
people. Besides that, the term speaking is not only how students can understand about sociolinguistic competence, for examples, why, when, and how to speak a language, but also, they have to master how the linguistic competence is produced, for examples, vocabulary, grammar, and pronunciation (Khorashadyzadeh, 2014). Furthermore, Burns in Bachtiar (2006, as cited in Abubakar 2015) stated that expressing ideas, information and feeling to people are part of verbal communication in speaking. Therefore, based on the definitions above, speaking is a process to deliver information or ideas to other people through oral communication.

\section{B. The Concept of Teaching Speaking}

According to Widyaningsih \& Robiasih (2018), a teacher who teaches speaking must find a good strategy to teach speaking because a teacher's way in teaching speaking influences students' success in learning speaking. Hence, teachers must apply good strategies which can develop students' speaking skills. This thing is related to a statement which was said by Anjaniputra (2013) that in various language programs, teaching speaking has an important role and teaching outcome is influenced by teaching strategies. Teachers have to implement a good strategy which can arouse students' interest, so they can be encouraged to speak well. In addition, Thornbury (2005) asserted that learners can apply their language use in real life and activate language knowledge automatization through communicative tasks. Moreover, communicative tasks are the application of Project-Based Learning (PBL) model.

\section{The Definitions of Project-Based Learning (PBL)}

There are several basic understandings about PBL. Project-Based Learning (PBL) is a learning model which emphasizes students' activities and giving freedom to students to improve their potential in the learning process (Ismuwardani, Nuryatin, \& Doyin, 2019). Then, it is similar to Jacques, Bissey, and Martin (2016)'s opinions which stated that PBL emphasizes students to work in groups or individually in order to they can improve their knowledge, skills and analyze several challenges and problems in their daily life. Besides that, PBL is a model which teaches students to more focus on learning concepts. In addition, Mali (2016) claimed that Project-Based Learning is a learning model through a project which focuses on studentcentered, learner autonomy, collaborative learning, and learning through various tasks. 
Furthermore, according to Cintang, Setyowati, \& Handayani (2017), there are several roles for teachers and students in PBL. In implementing PBL, teachers do not have a dominant role in teaching. It is because they only have some roles such as facilitator, supervisor, motivator, and evaluator. On the other hand, students have more active roles than teachers in PBL. They have a lot of activities, compared to teachers.

Moreover, based on Marisah \& Robiasih (2017), there are four stages of applying $\mathrm{PBL}$ in learning speaking. First, deliberation of preparing the activities. Second, devising the project activities which will be done. Third, implementing the project activities in a group. Fourth, making reflection and doing evaluation by giving feedback both from teachers and students in other groups.

\section{The Advantages of Project-Based Learning (PBL)}

There are a lot of advantages of PBL which can improve students' skills in the learning process. According to Westwood (2008), there are some advantages in applying PBL. First, students can improve their collaborative learning and team working skills through PBL. It is because students can work together with each other in a group to produce good results. Second, almost all curriculum fields are suitable to be applied PBL model. In the learning process students are required to be active, so through $\mathrm{PBL}$, they will be more involved in the learning. Third, students can improve their motivation and self-determination because they have the responsibility for their own learning. When students do a good project and get satisfaction, they will be more motivated in learning.

In addition, in applying PBL model, students learn through facts and use high-level thinking. It is because in doing a project, students will find some problems. Consequently, they can hone their thinking skills to be able to analyze each problem critically, so they can complete their project. Besides that, students could learn various knowledge and skills through PBL (Tamim and Grant, 2013). It happened because PBL was done in groups, so they had to discuss the project such as giving ideas or suggestions and solving problems. Moreover, students can apply their learning into practice directly through project work (Booth, 1986). Through PBL students can learn into real life because they apply the materials which have learned before. 


\section{E. The Concept of English Fun Fair}

Project-Based Learning (PBL) is one of the models which often uses in speaking. One of the implementations of PBL in Speaking for Social Purposes course is English Fun Fair. Mali (2018) postulated that English Fun Fair is a project where students can learn to communicate English with other people outside their class. Then, he stated that students work in a group to make and sell food or drinks. After that, students have roles as sellers and other people have roles as customers.

Based on the definition above, this project is carried out in groups where students and other people play roles in the project. According to Mali (2018)'s research, the students had to be explained the goal of the project before they did it. Besides that, the lecturers had to teach materials related to the project because they had to apply the materials directly. In addition, the students were given a deadline to do some preparation, for examples, dividing some jobs of each group and deciding what food or drinks to be sold. In English Fun Fair, the students were assessed by their lecturers about their performances, such as the way they spoke in English.

Furthermore, in this fair, visitors could buy some tickets which were given to students when they bought students' food and drink in every stand. Thus, the students had to attract visitors to buy their product, so they could collect a lot of tickets. Moreover, the students could apply their materials which have taught by their lectures, for examples, greeting people, handling conversation, and selling products. After the fair was finished, the students could exchange all the tickets they got into money to the committee. From the money they gained, students could participate in charity activities both outside and inside the university by granting the money (Sinanu, 2017 as cited in Mali, 2018).

\section{F. Previous Studies on Project-Based Learning (PBL)}

There are several studies related to the implementation of PBL in learning speaking. Tamim and Grant (2013) did a study to examine teachers' opinions about the implementation of PBL. This study involved six teachers who taught in four until twelve grades from public and private schools. Through this study, they found that one of the PBL impacts could develop students' communication skills because students worked in a group. They could be more engaged in the learning process to share ideas with their 
friends. Therefore, this study only focused on teachers' way in teaching speaking.

Another study in 2015 was conducted by Behtash and Sarlak in Islamic Azad University of Chabahar (IAUC), Iran. The university applied PBL as the model for teaching speaking. In this study, they investigated how PBL could influence Iranian EFL beginners in learning speaking. The participants were forty-five Iranian adult EFL students at elementary level. The result declared that they believed EFL students could get a positive effect in improving their speaking skills through PBL (Behtash \&Sarlak, 2017).

The similar study about English Fun Fair as the PBL implementation was carried out by Mali (2018) in at a private university in Central Java, Indonesia. The participants were Speaking for Social Purposes students. This study explained about English Fun Fair was a project which was used for assessing EFL students in their speaking performances. However, he only concerned about how the implementation of PBL itself. Therefore, this study was different from Mali's study. It happened because the researchers focused on how the students' perceptions which had experienced English Fun Fair as the implementation of PBL.

\section{G. Theoretical Framework}

In conclusion, learning speaking needs a good learning model which can motivate students. One of the models is Project-Based Learning (PBL). PBL requires students to be active in learning speaking. Then, one of the implementations of PBL is English Fun Fair project. Students can develop their communication skills in doing the project with their friends. Through the project, teachers teach students to learn through real experiences, so they can think more creatively. Besides that, the use of PBL model can make students improve their abilities to solve problems by discussing with their group.

\section{METHOD}

The study was intended to point out how English Fun Fair could influence students' learning process. To achieve the research objective, the study used a qualitative method. According to Mason (2002), there are some characteristics of the qualitative method. First, the method has as an interpretive position which related to how to understand, experience, and 
produce the world of social. Second, based on data retrieval methods which are susceptible and adjustable in a real context, accordingly, through the qualitative method; a scientifically systematic investigation tries to build a holistic, mostly narrative which aims to give information about a social or cultural phenomenon to researchers (Astalin, 2013).

\section{A. Context of the Study}

The study was conducted in the first Semester of 2019/2020 Academic Year. The location of the study was at English Language Education Program, Faculty of Language and Arts in at a private university in Central Java, Indonesia. The study was taken in this program because it has Speaking for Social Purposes classes which were related to this study. The reason for choosing the class was students had to do a project named English Fun Fair as one of the activities.

\section{B. Participants}

The participants of the study were fifty (50) students in ELEP, at a private university in Central Java, Indonesia They were ten (10) participants from the batch 2016, eighteen (18) participants from the batch 2017, and twenty-two (22) participants from the batch 2018 who had taken Speaking for Social Purposes course and had done English Fun Fair project. The participants were selected by using convenience sampling. It was because of the accessibility and availability of the participants in conducting the study to get the maximum results (Etikan, Musa, \& Alkassim, 2016). Then, they had gained experience and knowledge in doing English Fun Fair. Also, they could show their responses regarding the project related to the research question.

\section{Data Collection Methods}

In this study, the researchers used two kinds of instruments to collect the data. The first instrument was open-ended questionnaire. Dornyei \&Taguchi (2010) stated that through open-ended questionnaire, people can express their opinion more freely. This open-ended questionnaire consisted of five questions. The researchers translated the questions into Indonesian, so the participants could answer them easily. Therefore, they would understand more about every question and gave responses more deeply (please refer to appendix A).

On the other hand, to support the questionnaire data, the researchers conducted a semi-structured interview. There were three students who were 
interviewed. The interviews used Indonesian which is the participants' first language. The purposes of the interviews were to follow up on the questions in the questionnaires and to clarify the answers from the interviewees. The interviewer can expand and investigate the interviewees' responses more deeply through a flexible interview which named semi-structured interview (Rubin \& Rubin, 2005 as cited in Alsheenqeti, 2014). By conducting the interviews, the researchers could ask probing questions to the interviewees while using the interview protocol.

\section{Data Collection Procedures}

The researchers did those following steps to collect the research data. First, the researchers asked permission to the lecturer. Second, the student respondents were asked to fill the questionnaires.

After collecting the data by using the questionnaires, the researchers conducted the semi-structured interviews. Before doing the interviews, the researchers gave some explanation about the interviews' questions, so the participants could prepare some answers. Then, the interviews were recorded by using a voice recorder in a handphone. After the interviews were done, the recordings were transcribed.

\section{E. Data Analysis Procedures}

The data analysis was taken from the questionnaires and interviews. After collecting the data by using the questionnaires, the researchers read all the answers. Then, the questionnaire sheets were classified to find out several participants who filled out the interview consent to be interviewed. The the interview results were then transcribed. Afterward, the data were analyzed using thematic analysis. Based on Braun and Clarke (2006), thematic analysis focused on reading and coding the data. Finally, conclusions were drawn from the findings.

\section{FINDINGS AND DISCUSSIONS}

This section presented the result of the questionnaires and interviews data. Based on the data results, there were various perceptions from fifty (50) participants about English Fun Fair. The participants' perceptions were the drawn into two themes, namely the benefits of English Fun Fair and the 
challenges of getting involved in English Fun Fair. Each theme was supported by some excerpts from the questionnaires and interviews data.

\section{A. The Benefits of English Fun Fair}

According to the data analysis, there were some benefits which the participants got from the project. They expressed their experiences which included some aspects, such as improving students' speaking skills, improving students' self-confidence, developing collaborative skills, learning "how to sell techniques", and getting fun in the learning. Table 1 displayed the data which had analyzed into several sub-themes.

Table 1:

The Benefits of English Fun Fair

\begin{tabular}{lc}
\hline \multicolumn{1}{c}{ Students' Perceptions } & $\begin{array}{c}\text { Number of } \\
\text { Participants }\end{array}$ \\
\hline Improving students' speaking skills & $46(36,51 \%)$ \\
\hline Improving students' self-confidence & $25(19,85 \%)$ \\
\hline Developing collaborative skills & $9(7,14 \%)$ \\
\hline Learning “how to sell” techniques & $19(15,07 \%)$ \\
\hline Getting fun in the learning & $27(21,42 \%)$ \\
\hline Total Number & $126(100 \%)$ \\
\hline
\end{tabular}

The table above presented several benefits which the students gained in the project. Those aspects could influence students in the learning process. Improving students' speaking skills became the main benefit which students gained. However, the minor benefit was developing collaborative skills.

\section{Improving Students' Speaking Skills}

Improving students' speaking skills was one of the many benefits mentioned by the majority of the participants. Forty-six (46) participants $(36,51 \%)$ said that they could improve their speaking skills both during and after doing the project. Some participants asserted:

\section{Excerpt 1:}

...when I offered my products, I had to speak English, so it was very helpful in improving my speaking skills. 
(Student 1's interview answer, December 6, translated by the researchers)

Excerpt 2:

One of the Speaking for Social Purposes class goals is communicating by using English. Thus, I had to speak English in public, so it could improve my speaking skills in English.

(Student 2's interview answer, December 6, translated by the researchers)

Excerpt 3:

In this project, I was forced to speak English spontaneously, although I had prepared before doing the project. Therefore, I could be motivated to speak English indirectly because I had to use English during the project.

(Student 3's interview answer, December 6, translated by the researchers)

From the excerpts above, the participants could enhance their speaking skills through English Fun Fair. It was because they had to speak English in public spontaneously while selling their products. A similar finding could be found in Marisah \& Robiasih (2017)'s research. Based on their research, applying a project in learning could improve students' speaking skills indirectly because they got a lot of chances to speak English. Another research was conducted by Behtash \& Sarlak in Islamic Azad University of Chabahar (IAUC), Iran. They claimed that through PBL, EFL students could get a positive impact in developing their speaking skills (Behtash \& Sarlak, 2017). Therefore, the project was very useful for improving students' speaking skills.

\section{Improving Students' Self-Confidence}

Another benefit which faced by twenty-five (25) participants (19,85\%) was about self-confidence. They believed about how they could improve their self-confidence.

\section{Excerpt 4:}

I could become more confident in speaking English, after doing English Fun Fair. Also, I used to speak English without looking at a note. 
(Student 1's questionnaire answer, November 14, translated by the researchers)

\section{Excerpt 5:}

Through the project, I had to be confident in selling products. It was because I had to speak English in promoting and selling the products, so I could increase my confidence.

(Student 2's questionnaire answer, November 14, translated by the researchers)

Based on some excerpts above, both during and after doing the project, the participants could increase their self-confidence. It happened because they had to promote and sell the products by using English. The findings above were supported by some researchers who did a study at a university in Palembang. Jaya, Hermansyah, \& Rosmiyati (2019) postulated that students could build their self-confidence through Project-Based Learning. Moreover, the result of the study by Marisah and Robiasih (2017) indicated that in doing a speaking project, students had a lot of chances to speak English, so they could boost their confidence indirectly. Hence, the project was very beneficial because the participants could improve their self-confidence.

\section{Developing Collaborative Skills}

English Fun Fair is a project which is done in a group. Hence, nine (9) participants $(7,14 \%)$ also responded to the questionnaires that they could enhance their teamwork skills in doing the project with their friends. One of the participants' statements was:

Excerpt 6:

Based on my experience, I could enhance a cooperative attitude in my group. I learned how to work with my friends in a group in order to produce a good result.

(Student 3's questionnaire answer, November 14, translated by the researchers)

The excerpt above showed that collaborative skills could be improved through the project by interacting with friends. Then, there was a relation between collaborative learning and team work with the students' English 
learning. The students could learn from each other in a group. Thus, the students who had good skills in English could help their friends to learn English, so they could get good grades in this project. Since this project is one of the implementations of PBL model, there are some statements which support the finding.

This is similar to Westwood's (2008) opinion which stated that through $\mathrm{PBL}$, students can improve their team working and collaborative learning skills. It happens because they have to work together with their friends in a group to produce good results. In line with the statement, Mali (2016) said that students can learn collaboration directly with their friends in a group project. Consequently, the participants could enhance their collaborative skills in the project.

\section{Learning "How to Sell" Techniques}

There were nineteen (19) participants $(19,07 \%)$ who mentioned that they could learn a lot of selling techniques through English Fun Fair because the project required the students to sell a product. Since the project was the implementation of $\mathrm{PBL}$, the participants could learn through real experiences. They could develop their English skill while selling their products. A participant said:

\section{Excerpt 7:}

Through English Fun Fair, I got new knowledge about selling techniques. Then, I could practice selling by speaking English with a lot of visitors.

(Student 4's questionnaire answer, November 14, translated by the researchers)

From the excerpt, it could be seen that the participant could learn English while applying the selling techniques. The participant's statement was supported by Mali (2018)'s research. He stated that through the project, students tried to offer and sell their products to visitors by interacting in English. Therefore, besides improving English skills, the selling techniques could be learned through the project in the real context.

\section{Getting Fun in the Learning}

The next benefit of English Fun Fair was about getting fun in the learning. This speaking project was done outside the class in which the 
students had to speak English by selling things to visitors. Thus, twenty-seven (27) participants $(21,42 \%)$ claimed that their speaking was not monotonous because they could learn it by applying some materials in the class into a real situation. This was what a participant mentioned:

Excerpt 8:

The concept of English Fun Fair is fun and unique. It happened because I learned to speak English by selling some products with my friends. Also, I had to make a stand to sell the products, so visitors could be interested to buy it.

(Student 5's questionnaire answer, November 14, translated by the researchers)

According to the excerpt above, the project was fun learning because the participant could learn English in a real context. Similarly, Chiang and Lee (2016) in their study pointed out that Vocational High School students in Taiwan enjoyed practicing PBL because they could share their experiences with their friends. Then, they felt happy when they could help their friends in doing the project. Also, Seidel \&Aryeh (2002) as cited in Agustina (2016) said that students could learn fun activities, work with their friends in a group, and solve some problems through project-based learning in a real context. Accordingly, fun learning needed to be applied to the students, so they did not get bored quickly. It was because when they enjoyed learning, they could learn easily.

\section{B. The Challenges of Getting Involved in English Fun Fair}

Besides several benefits which the participants obtained from English Fun Fair, they also faced some challenges when they did the project. The challenges were divided into four aspects. Those were finding an appropriate concept, difficulties to finance the project, problems in team collaboration, and problems in speaking skills. The data results were grouped into some subthemes as shown in Table 2.

\section{Table 2:}

The Challenges of Getting Involved in English Fun Fair

\begin{tabular}{ll}
\hline Students' Perceptions & Number of \\
Participants
\end{tabular}


Apriliani, A.I. \& Listyani, Student's Perceptions on English Fun Fair as an

Implementation of Project-Based Learning in Speaking for Social Purposes Classes

\begin{tabular}{lc}
\hline Finding the appropriate concept & $11(25 \%)$ \\
\hline Difficulties to finance the project & $6(13,64 \%)$ \\
\hline Problems in team collaboration & $5(11,36 \%)$ \\
\hline Problems in speaking skills & $22(50 \%)$ \\
\hline Total Number & $44(100 \%)$ \\
\hline
\end{tabular}

Based on table 2, the data indicated that there were four challenges which the students faced. Speaking skills were the highest challenge. Meanwhile, the lowest challenge experienced by students was team collaboration.

\section{Finding the Appropriate Concept}

According to eleven (11) participants' responses (25\%), they stated that one of the challenges they faced was when finding the concept. They had to make a concept which could attract a lot of visitors to buy their products. Some participants mentioned:

Excerpt 9:

The challenge which we faced was we had to create a creative idea about what products which would we sold in English Fun Fair. It was because creating an idea is an important thing to make an activity. We had to make many visitors could be interested to buy our products.

(Student 6's questionnaire answer, November 14, translated by the researchers)

Excerpt 10:

Before doing English Fun Fair, my friends and I had to think about what products which we would sell. We had to sell interesting things. Also, we had to create a good decoration for our stand, so many visitors could be attracted to visit our stand.

(Student 7's questionnaire answer, November 14, translated by the researchers)

Although finding the concept was difficult, they tried to discuss it with their friends by collecting various ideas. Then, they voted to decide the most chosen ideas. Considering in doing a speaking project, the first thing to do is 
finding a concept or theme. An interesting and unique concept can make a good impression on the project. It also determines the success of the project itself.

\section{Difficulties to Finance the Project}

Another challenge which six (6) participants $(13,64 \%)$ faced was about funds. Since the project required the students to sell products, they needed a lot of funds for preparing the project, for examples, buying the materials and decorating their stand. This was what one of the participants mentioned in the questionnaire:

\section{Excerpt 11:}

In making a creative project, we needed much money. Our group had limited funds, so we tried to save the money in preparing the project.

(Student 8's questionnaire answer, November 14, translated by the researchers)

It is indeed difficult to finance a project because funds have an important role in preparing a project. If the funds are insufficient, the project can be hampered or cannot work well. Hence, the participants tried to save their money. They minimized the purchase of things which were really needed. On the other hand, based on the questionnaires, there were several roles of lecturers and students in dealing with the challenges. The first challenge was finding the appropriate concept. The lecturers provided some examples of concepts, so the students got an insight into the concept. While the students collected several ideas and then, they chose the best idea. The second challenge was difficulties to finance the project. To solve this problem, the lecturers gave some ideas and suggestions to the students to buy affordable items, for example, giving a shop recommendation which sold cheap products. Besides that, the students also minimized the buying cost in order to save their money.

\section{Problems in Team Collaboration}

Though many participants could improve their collaborative skills through this project, other participants could not improve it. It was because five (5) participants $(11,36 \%)$ had problems with their friends in a group. They had problems in gathering their friends to discuss their projects. It happened 
because they had different class schedules. Besides that, they got difficulties in bringing ideas together because some people had limitations to share their ideas. As a participant asserted:

\section{Excerpt 12:}

One of the challenges which I faced when doing English Fun Fair was my friends in my group itself. My friends and I got difficulty in controlling them, so we could not unite all ideas to get a decision.

(Student 9's questionnaire answer, November 14, translated by the researchers)

The statement is supported by Beebe and Masterson (2003) as cited in Burke (2011). They asserted that one of the disadvantages of working in a group is some group members do not have many opportunities to share their ideas in making a decision. It is because a person dominates the group discussion, so other group members did not get satisfaction. In addition, a study showed that another problem of group project was differences in group members' schedules. The problem caused some group members could not work optimally because they had limited time to work together (LaBeouf et al,, 2016).

Thus, to handle those problems, the students looked for the right time where all members of the group could gather and discuss the project together. Then, to unite the idea, each person in a group had to share the ideas. Next, they voted to determine the most chosen idea. In addition, Burke (2011) stated that to solve the problems which occur in a group, the instructor can help the group in making some ways to deal with unproductive group members.

\section{4. $\quad$ Problems in Speaking Skills}

In this project, twenty-two (22) participants (50\%) got difficulty related to speaking skills itself. They mentioned a lot their difficulties in speaking English in public. Some participants said:

Excerpt 13:

I still felt afraid when I spoke English. I felt that my mouth was trembling. Then, I focused on accuracy than fluency 
because grammar was the most important thing for me. Therefore, I could not speak English fluently.

(Student 2's interview answer, December 6, translated by the researchers)

Excerpt 14:

During the project, I still got difficulty in speaking English. Particularly, when I found some new vocabulary and I did not know the meaning.

(Student 3's interview answer, December 6, translated by the researchers)

The findings were similar to some studies about problems in speaking class generally. Rahmaniah, Asbah, \& Nurmasitah (2018) said that students faced several aspects of problems in speaking English. There were vocabulary, grammar, pronunciation, fluency, and comprehension aspects. Besides that, Hadijah (2014) in her study also concluded that a lack of vocabulary and stutter of speaking were several reasons of speaking problems. Consequently, the students did several things to solve those problems such as practicing to speak English continuously and learning vocabulary with their friends. Moreover, based on Hadijah (2014)'s study, teachers had to motivate their students to enhance their speaking skills. It happened because when they had good speaking skills, they could handle their problems.

Therefore, the results of the study revealed that the students got some benefits and challenges in English Fun Fair. The students could improve their speaking skills, self-confidence, and collaboration skills. In addition, they could learn the selling techniques and get fun in the learning. Moreover, the students perceived the concept, the finance, team collaboration, and speaking skills were several challenges which influenced their learning process.

\section{CONCLUSION}

This study presents about students' perceptions towards English Fun Fair. As mentioned before, the research question is What are students' perceptions on English Fun Fair as the implementation of Project-Based Learning (PBL) model in Speaking for Social Purposes classes? Based on the findings, there 
were a lot of students' perceptions about English Fun Fair. From the perceptions, it could be concluded that there were various benefits and several challenges which the students learned from English Fun Fair. As the benefits, the students could improve their speaking skills and self-confidence. It happened because they learned how to speak English well in a real situation which they could boost their motivation to be confident in speaking. Then, the students could improve their collaborative skills since the project was done in a group, so they could learn by working together with their friends. Besides that, they could learn the selling techniques and get fun in the learning. Through this project, the students learned to speak English while selling their products to people. Hence, their speaking learning was not monotonous in class because they could practice it in a real context.

However, the students still encountered some challenges in English Fun Fair. The students got difficulties in finding the concept because they had to decide what theme and product to sell. Besides the concept, they had financial problems because they had to buy or make the product which needed a lot of funds. In addition, the students faced a challenge related to team collaboration, such as gathering with friends and bringing out some ideas. Furthermore, they also had problems in speaking skills since they had to speak in public.

This study also has a limitation. It only focused on the speaking project which was Project-Based Learning in Speaking for Social Purposes classes. According to the findings, there are several other aspects which may be possible to occur in other speaking activities like difficulties to master materials and anxiety problems. Therefore, for future study, it will be better if the study does not only focus on a speaking project but also focus on another speaking activity. In addition, this study proposes several recommendations about the benefits of implementing PBL in speaking class. Lecturers can take some benefits of the project as a reference in teaching speaking. Also, they can contribute in teaching speaking by implementing PBL. Furthermore, for students, they can enhance their speaking and other skills which support their learning process.

\section{REFERENCES}

Abubakar, M. S. (2015). Improving the second-year students' speaking ability through project-based learning (PBL) at MTSN Model Makassar. 
92 Celt: A Journal of Culture, English Language Teaching \& Literature, Volume 20, Number 1, June 2020, pp. 73- 95

ETERNAL, 1(2), 216-228. doi: https://doi.org/10.24252/Eternal.V12.2015.A5

Agustina, N. (2016). Assessment of project-based learning in science class. Jurnal Siliwangi, 2(2), 137-150. Retrieved from http://jurnal.unsil.ac.id/index.php/jspendidikan/article/viewFile/95/6 5

Alsheenqeti, H. (2014). Interviewing as a data collection method: A critical review. English Linguistics Research, 3(1), 39-45. doi: http://dx.doi.org/10.5430/el r.v3n1p39

Anjaniputra, A. G. (2013). Teacher's strategies in teaching speaking to students at secondary level. Journal of English and Education, 1(2), 1-8. Retrieved from http://ejournal.upi.edu/index.php/LE/article/download/577/434

Astalin, P. K. (2013). Qualitative research designs: A conceptual framework. International Journal of Social Science $\mathcal{E}$ Interdisciplinary Research, 2(1), 118124. Retrieved from https://pdfs.semanticscholar.org/baa7/c8f5577b0b1798b5e9f559f5cba e32bf1a36.pdf

Behtash, E. Z., \& Sarlak, T. (2017). The effect of project-based learning (PBL) on the components of speaking ability of Iranian EFL beginner learners. Journal of Applied Linguistics and Language Research, 4(3), 119-130. Retrieved from https://pdfs.semanticscholar.org/2b4d/379bbc3e2d88d8917e5eeddc39 11e9171d92.pdf?_ga=2.109389765.1906654413.1561211508177607081.1561211508

Booth, D. L. F. (1986). Project work. Oxford: Oxford University Press.

Braun, V., \& Clarke, V. (2006). Using thematic analysis in psychology. Qualitative Research in Psychology, 3(2), 77-101. doi: http://dx.doi.org/10.1191/1478 088706qp063oa

Burke, A. (2011). Group work: How to use groups effectively. The Journal of Effective $\quad$ Teaching, 87-95. Retrieved from https://uncw.edu/jet/articles/ vol11_2/burke.pdf 
Chiang, C. L., \& Lee, H. (2016). The effect of project-based learning on learning motivation and problem-solving ability of vocational high school students. International Journal of Information and Education Technology, 6(9), 709-712. doi: http://10.7763/IJIET.2016.V6.779

Cintang, N., Setyowati, D. L., \& Handayani, S. S. D. (2017). Perception of primary school teachers towards the implementation of project-based learning. Journal of Primary Education, 6(2), 81-93. Retrieved from https://journal.unnes.ac.id/sju/index.php/jpe/article/download/1755 2/8811/

Dornyei, Z., \& Taguchi, T. (2010). Questionnaires in second language research: Construction, administration, and processing (2nd ed). New York: Routledge. Retrieved from https://d1123.zlibcdn.com/download/book/1190313?token=f36f3cbcaa 63a96187f28f1dc7c4c79b

Etikan, I., Musa, S. A., \& Alkassim, R. S. (2016). Comparison of convenience sampling and purposive sampling. American Journal of Theoretical and $\begin{array}{llll}\text { Applied } & \text { Statistics, } & 5(1), & 1-4 .\end{array}$ https://doi.org/10.11648/j.ajtas.20160501.11

Hadijah, S. (2014). Investigating the problems of English speaking of the students of islamic boarding school program at STAIN Samarinda. Dinamika Ilmu, 14(2), 240-247. doi: https://doi.org/10.21093/di.v14i2.16

Ismuwardani, Z., Nuryatin, A., \& Doyin, M. (2019). Implementation of project-based learning model to increased creativity and self-reliance of students on poetry writing skills. Journal of Primary Education, 8(1), 51-58. doi: https://doi.org/10.15294/jpe.v8i1.25229

Jacques, S., Bissey, S., \& Martin, A. (2016). Multidisciplinary project-based learning within a collaborative framework. International Journal of Emerging Technologies in Learning, 11(12), 36-44. doi: https://doi.org/10.3991/ijet.v1 1 i1 2.5996

Jaya, A., Hermansyah, \& Rosmiyati., E. (2019). The implementation of project-based learning in increasing speaking achievement and selfconfidence. Indonesian Educational Administration and Leadership Journal 
94 Celt: A Journal of Culture, English Language Teaching \& Literature, Volume 20, Number 1, June 2020, pp. 73-95

(IDEAL), 1(1), 4-14. Retrieved from https://onlinejournal.unja.ac.id/IDEAL/article/download/660 5/4305/

Khorashadyzadeh, A. (2014). Why to use short stories in speaking classes? International Journal of Foreign Language Teaching in the Islamic World, 2(1), 9-15. Retrieved from http://www.fltj.org/files/January\%202014/final_ Mr_Khorashady_2.pdf

LaBeouf, J. P., Griffith, J. C., \& Roberts, D. L. (2016). Faculty and student issues with group work: What is problematic with college group assignments and why? Journal of Education and Human Development, 5(1), 13-23._doi:_http://dx.doi.org/10.15640/jehd.v5n1a2

Mali, Y. C. G. (2016). Project-based learning in Indonesian EFL classrooms: From theory to practice. Indonesian Journal of English Education, 3(1), 89. 105. doi: http://dx.doi.org/10.15408/ijee.v3i1.2651

Mali, Y. C. G. (2018). Project-based EFL speaking activity: The English funfair. Accents Asia, 10(2), 61-68. Retrieved from http://www.issues.accentsasia.org/issues/10-2/Mali.pdfm

Marisah, A., \& Robiasih, RR. H. (2017). The implementation of project-based learning to improve vocational students' speaking skills. Journal of English Language and Language Teaching (JELLT), 1(2), 27-32. Retrieved from http://jurnal.ustjogja.ac.id/index.php/JELLT/article/download/1868/ 1037

Mason, J. (2002). Qualitative researching (2nd edn). London: Sage Publications. Retrieved from https://dl114.zlibcdn.com/download/book/1201 041?token=90 6ea3170ee70a35ba311f4bebde6cff

Rahmaniah, R., Asbah, \& Nurmasitah. (2018). The speaking difficulties encountered by non-English students in language classroom. Journal of English Language Teaching and Linguistics (JELTL), 11(2), 22-25. doi: https://doi.org/10.317 64/leltj.v12i2.749

Suryani, L. (2015). The effectiveness of role-play in teaching speaking. ELTIN Journal, 3(2), 106-109. doi: https://doi.org/10.22460/eltin.v3i2.p\%25p

Tamim, S. R., \& Grant, M. M. (2013). Definitions and uses: Case study of teachers implementing project-based learning. Interdisciplinary Journal of 
Problem-Based Learning, 7(2), 72-101. doi: https://doi.org/10.7771/15415015.1323

Thornbury, S. (2005). How to teach speaking. Harlow: Pearson Education Limited.

Ur, P. (1996). A course in language teaching. Cambridge: Cambridge University Press. Retrieved from https://dl140.zlibcdn.com/ download/book/1162252?token=3fca040e1010d3d8d87bb40d3164a1c 5

Westwood, P. (2008). What teachers need to know about teaching methods. Camberwell: ACER Press. Retrieved from https://dl114.zlibcdn. com/ download/book/863366?token=6836afaa0bc668ae735bce3aa1a05c8c

Widyaningsih, D., \& Robiasih, RR. H. (2018). Teacher's strategies in teaching speaking skill for eleventh grade students at SMA Bopkri 2 Yogyakarta. Journal of English Language and Language Teaching (JELLT), 2(1), 46-58. Retrieved http://jurnal.ustjogja.ac.id/index.php/JELLT/article/download/ $2714 / 1549$ 